\title{
The adsorption of fungal ice-nucleating proteins on mineral dusts: a terrestrial reservoir of atmospheric ice-nucleating particles
}

\author{
Daniel O’Sullivan ${ }^{1}$, Benjamin J. Murray ${ }^{1}$, James F. Ross ${ }^{2, a}$, and Michael E. Webb ${ }^{2}$ \\ ${ }^{1}$ Institute for Climate and Atmospheric Science, School of Earth and Environment, University of Leeds, Leeds, UK \\ ${ }^{2}$ School of Chemistry and Astbury Centre for Structural Molecular Biology, University of Leeds, Leeds, UK \\ ${ }^{\text {a }}$ now at: School of Chemistry, University of Bristol, Bristol, UK \\ Correspondence to: Daniel O’Sullivan (d.osullivan@leeds.ac.uk) and Benjamin J. Murray (b.j.murray@leeds.ac.uk)
}

Received: 14 December 2015 - Published in Atmos. Chem. Phys. Discuss.: 18 January 2016

Revised: 18 May 2016 - Accepted: 26 May 2016 - Published: 29 June 2016

\begin{abstract}
The occurrence of ice-nucleating particles (INPs) in our atmosphere has a profound impact on the properties and lifetime of supercooled clouds. To date, the identities, sources and abundances of particles capable of nucleating ice at relatively low supercoolings $\left(T>-15^{\circ} \mathrm{C}\right)$ remain enigmatic. While biomolecules such as proteins and carbohydrates have been implicated as important high-temperature INPs, the lack of knowledge on the environmental fates of these species makes it difficult to assess their potential atmospheric impacts. Here we show that such nanoscale ice-nucleating proteins from a common soil-borne fungus (Fusarium avenaceum) preferentially bind to and confer their ice-nucleating properties to kaolinite. The ice-nucleating activity of the proteinaceous INPs is unaffected by adsorption to the clay, and once bound the proteins do not readily desorb, retaining much of the activity even after multiple washings with pure water. The atmospheric implications of the finding that biological residues can confer their icenucleating ability to dust particles are discussed.
\end{abstract}

\section{Introduction}

Aerosols in our atmosphere can modify cloud properties by acting as cloud condensation nuclei (CCN) and icenucleating particles (INPs). While atmospheric INPs are rare in comparison to CCN (DeMott et al., 2010; Pruppacher and Klett, 1997), they exert a disproportionate effect on cloud properties such as albedo, extent, lifetime, dynamics and conversion to precipitation (Rosenfeld et al., 2011; Storelvmo et al., 2011; Boucher et al., 2013). Biological par- ticles in our atmosphere are the most efficient known catalysts relevant for ice formation in supercooled cloud water droplets (Murray et al., 2012; Hoose and Möhler, 2012). Certain bacteria, fungal spores and pollen grains can facilitate the freezing of supercooled cloud water droplets at temperatures where common inorganic ice-nucleating particles such as mineral dusts or black carbon are comparably inactive $\left(T>-15^{\circ} \mathrm{C}\right)$ (Murray et al., 2012; Hoose and Möhler, 2012; Fröhlich-Nowoisky et al., 2015; Pummer et al., 2015; O'Sullivan et al., 2015). However, number densities of these supermicron biological particles are typically many orders of magnitude lower than those of their inorganic counterparts at altitudes relevant for supercooled clouds (Hoose et al., 2010).

The majority of past studies on the atmospheric implications of biological ice nucleators have focused on examining the activities of supermicron cellular entities such as bacteria, fungal spores and pollen grains. However, there is evidence that subcellular portions of biological INPs, such as proteins and carbohydrates, can be readily released from terrestrial INPs such as fungal mycelia or pollen grains on contact with water and continue to exhibit the ice-nucleating abilities of the parent particles (Pouleur et al., 1992; Augustin et al., 2013; O'Sullivan et al., 2015; Fröhlich-Nowoisky et al., 2015; Pummer et al., 2012). Similarly in the oceans, subcellular INPs, thought to be associated with phytoplankton, have also been identified (Wilson et al., 2015; Schnell and Vali, 1975). This is important because the number densities of these nanoscale fragments can far outnumber those of the parent cellular particles. For instance, each single grain of pollen has roughly $10^{4}$ INPs at its surface, which are easily separable on contact with water (Augustin et al., 2013; 
O'Sullivan et al., 2015). Similarly, a single gram of Fusarium avenaceum harbours $10^{8}$ nano-sized INPs active at temperatures above $-7^{\circ} \mathrm{C}$ (O'Sullivan et al., 2015). These INPs appear to be proteinaceous as inferred from their thermal lability, combined with their susceptibility to treatment with Proteinase K (Hasegawa et al., 1994). However, given their size, these nanoscale INPs (nano-INPs) are unlikely to be directly aerosolized in abundance from surfaces. While readily lost from cells on wetting, significant questions remain regarding the environmental fates of biological nano-INPs. In particular, do these efficient INPs adsorb to larger particles which are more readily aerosolized such as soil mineral dusts, and critically, is activity retained upon adsorption?

Several recent studies have indicated that biogenic matter co-transported with soil dusts has an exceptional ability to catalyse the freezing of supercooled water droplets. Pratt et al. (2009) demonstrated that in mixed-phase clouds above Wyoming, mineral dust particles were the dominant ice crystal residues sampled, while $60 \%$ of these mineral dust particles were internally mixed with an observable amount of biogenic and/or humic-like substances. Similarly, co-lofted mineral dusts and biological materials have been demonstrated by Creamean et al. (2013) to represent a major contributor in the generation of precipitation over the Sierra Nevada on the west coast of the United States.

Laboratory-based studies have shown that organic matter in soils is a potent source of INPs, with activities much higher than those of the mineral components in the soils (Conen et al., 2011; O'Sullivan et al., 2014; Tobo et al., 2014; Hill et al., 2016). In the 1970s, Schnell (1977) performed experiments where distilled water was passed through a column of kaolinite capped with decaying leaf litter. Nuclei in the leaf litter were passed down through the column, leading to a dramatic increase in the ice nucleation activity of the kaolinite. Schnell suggested that biogenic materials became associated with the clay particles, imparting their ice-nucleating activity to the clay. Since this early study, it has been posited that the exceptional ice-nucleating abilities of fertile soil dust may stem from the incorporation of residues from bacterial, fungal and pollenaceous ice-nucleating particles (Conen et al., 2011; O'Sullivan et al., 2015; Fröhlich-Nowoisky et al., 2015). Very recently, it has been reported that nanoscale pollenaceous INPs, which are thought to be carbohydrates, retain their nucleating activity when internally mixed with mineral dusts particles (Augustin-Bauditz et al., 2016). However, to date it remains unclear as to whether cell-free icenucleating proteins, such as those derived from Fusarium fungi, can adsorb to and confer their exceptional nucleating activities to mineral dusts particles in soils.

Once adsorbed to mineral surfaces, degradation of biomolecules such as proteins, peptides and amino acids by soil microbes and enzymes is generally reduced (Gianfreda et al., 1991; Fiorito et al., 2008; Koskella and Stotzky, 1997; Calamai et al., 2000; Lozzi et al., 2001). Indeed, proteins and carbohydrates in soils can exhibit exceptionally long life- times, on the order of up to half a century (Schmidt et al., 2011). Furthermore, adsorbed biomolecules can continue to exhibit activity when attached to clay surfaces. For instance, bound enzymes continue to convert substrates (Leprince and Quiquampoix, 1996; Quiquampoix, 1987; Rao et al., 2000; Calamai et al., 2000), and bound insecticidal proteins from $B$. thuringiensis retain their ability to kill larvae (Koskella and Stotzky, 1997). However, once adsorbed to mineral surfaces, the magnitude of enzyme activities is typically reduced, and in some cases completely lost (Zimmerman and Ahn, 2011). Hence, it is necessary to study whether the activity of iceactive proteins is retained when bound to clay minerals.

Given recent findings that extracellular proteinaceous INPs (P-INPs) from common, globally distributed soil fungi are readily separated from the parent fungus upon contact with water (O'Sullivan et al., 2015; Fröhlich-Nowoisky et al., 2015), examination of their environmental fates is required to understand how they can add to the budget of atmospheric INPs. In this study, we examine the interactions of nanoscale ice-nucleating proteins from the soil-borne fungus Fusarium avenaceum with the common soil clay mineral kaolinite. It is demonstrated that, in the presence of cations commonly found in soil solutions, the P-INPs are rapidly adsorbed to the clay mineral, with the majority remaining bound even after successive washes. The implications of the finding that the proteins continue to exhibit their exceptional ice-nucleating abilities once they adsorb to mineral dust particles are discussed.

\section{Methods}

\subsection{Sample preparation}

Fusarium avenaceum was sourced from the Commonwealth Agricultural Bureau (CABI) and grown by incubation in sterile potato dextrose broth for 3 days at $28^{\circ} \mathrm{C}$. A portion of mycelium was separated from the broth and resuspended in $50 \mathrm{~mL}$ of Milli- $\mathrm{Q}^{\circledR}$ grade water. Residual potato dextrose broth on the mycelium was minor. Regardless of this, the potato dextrose broth itself was tested for ice nucleation activity, and no activity above the background (freezing of Milli-Q ${ }^{\circledR}$ purified water) was observed (Fig. S1 in the Supplement). The mycelial suspension was then agitated by hand, and the proteinaceous ice-nucleating particles were separated by filtration using $0.2 \mu \mathrm{m}$ cellulose acetate filters (Sartorius Stedim ${ }^{\circledR}$, Minisart 16534) and oil-free syringes.

To examine the affinity of cell-free proteinaceous icenucleating particles (P-INPs) to the $1: 1(\mathrm{Si}: \mathrm{Al})$ clay mineral kaolinite, the untreated clay was mixed together with an aqueous suspension containing P-INPs recovered by $0.2 \mu \mathrm{m}$ filtration of a Fusarium avenaceum suspension. Using the supernatant depletion method (Ralla et al., 2010; Ding and Henrichs, 2002; Lepoitevin et al., 2014), the clay was removed from the suspension by centrifugation, and resus- 


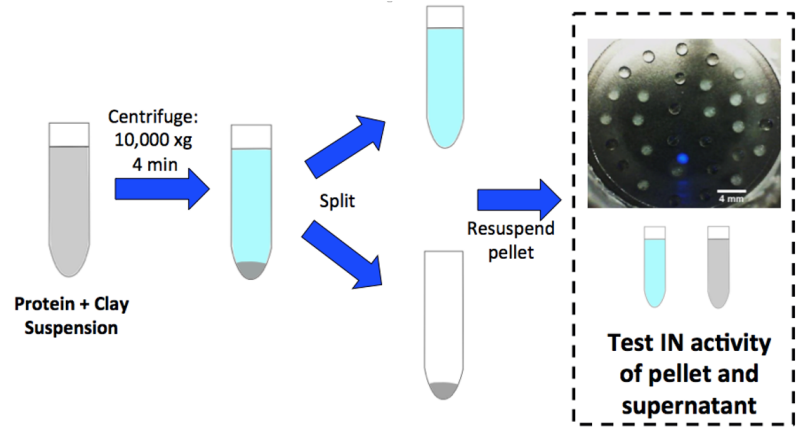

Figure 1. Schematic of the depletion method used to evaluate interactions between proteinaceous ice-nucleating particles (P-INPs) and the clay mineral kaolinite. Initially, suspensions containing the clay and protein were allowed to mix for a prescribed contact time. Following this, the clay was pelleted by centrifugation, the supernatant carefully removed and the remaining pellet resuspended in an equivalent volume of water $(1 \mathrm{~mL})$. The ice-nucleating activity of both the resuspended clay and the supernatant is then tested to examine for the presence of P-INPs.

pended in an equivalent volume of water (Fig. 1). Any freely suspended proteins would be expected to remain in the supernatant, while those bound to clay mineral particles would collect as a pellet at the bottom of the centrifuge tube. The icenucleating activity of both the resuspended clay, and particles which remained in the supernatant, were then determined using a microlitre droplet freezing technique (see Sect. 2.2).

For these adsorption experiments, $4 \mathrm{~mL}$ of a stock PINP suspension (derived from an initial concentration of $2 \times 10^{-2} \mathrm{~g} \mathrm{~mL}^{-1}$ of mycelium prior to filtration, followed by a 1/20 dilution after collection in the filtrate) was mixed with $1 \mathrm{~mL}$ of a stock suspension of Clay Mineral Society kaolinite $\mathrm{Kga}-1 \mathrm{~b}\left(0.125 \mathrm{~g} \mathrm{~mL}^{-1}\right)$ and diluted to $10 \mathrm{~mL}$ total. The kaolinite was dispersed in water by ultra-sonication and stirred magnetically for about $1 \mathrm{~h}$ to produce the stock suspension, before being mixed with the stock P-INP suspension. The effects of solution acidity were examined by modifying the initial $\mathrm{pH}$ with either $\mathrm{HCl}$ or $\mathrm{NaOH}$, and monitoring using a Hanna instruments glass $\mathrm{pH}$ meter. The effects of electrolytes was also probed, by adjusting the solution ionic strength to either 1 or $10 \mathrm{mM}$ with sodium chloride (Fisher, S/3160/5), calcium chloride dihydrate (Sigma, C3306) or magnesium chloride hexahydrate (Sigma, M2670). After a prescribed contact time (either $2 \mathrm{~h}$ or 2 days), $1 \mathrm{~mL}$ of the suspension was centrifuged at $10000 \times \mathrm{g}$ for $4 \mathrm{~min}$ to pellet the clay. The supernatant was then carefully removed by gentle decanting, and the use of a $50 \mu \mathrm{L}$ pipette if necessary. Following this, the pellet was resuspended in $1 \mathrm{~mL}$ of water and vortexed to disperse. Control experiments were performed in the absence of kaolinite with Milli- $\mathrm{Q}^{\circledR}$ purified water alone, or with $\mathrm{CaCl}_{2}$, showing that there was no significant preferential sedimentation of the protein (see Fig. S1). For desorption experiments, the clay pellet (and associated P-INPs) was re- peatedly washed in Milli- $\mathrm{Q}^{\circledR}$ purified water, resuspended and centrifuged again.

\subsection{Measurement of ice-nucleating activities}

The measurement of ice-nucleating activities was performed using the Leeds microlitre nucleation by immersed particles instrument ( $\mu \mathrm{L}-\mathrm{NIPI})$. The apparatus and experimental procedures have been described in depth elsewhere (O'Sullivan et al., 2014, 2015; Whale et al., 2015) and so are only briefly discussed here. 40-50 $1 \mu \mathrm{L}$ droplets were pipetted onto a $22 \mathrm{~mm}$ diameter silanized slide (Hampton Scientific), which was cooled from the underside using Stirling-engine-chilled aluminium stage (Grant-Asymptote, EF600). The headspace above the droplets was enclosed in a Perspex shield, and gently purged with $200 \mathrm{~cm}^{3} \mathrm{~min}^{-1}$ of nitrogen gas to prevent unwanted condensation. Nucleation events were detected using a USB camera embedded inside the external humidity control chamber by manually analysing the recorded video. For all experiments, a $1^{\circ} \mathrm{C} \mathrm{min}-1$ cooling rate was employed. The temperature error associated with the platinum resistance thermistor which monitored the aluminium cold stage was estimated as $\pm 0.4 \mathrm{~K}$. Each experiment was repeated twice, and the cumulative fraction frozen $(F)$ of droplets compiled as a function of temperature. Full crystallization at such high temperatures could take up to a few seconds; nucleation points were taken as the first observable instance of ice formation in the droplets.

\subsection{Data analysis}

From the cumulative fraction of droplets frozen $(F)$ as a function of temperature, the time-independent singular formulation can be used to describe the number of nucleating sites active at a given temperature contained within a given volume of water $(V)$ (Vali, 1971):

$K=\frac{-\ln (1-F)}{V}$.

Accordingly, the difference in the number of ice-nucleating sites between the supernatant and the resuspended clay pellet could be used as an indicator for the relative affinity of the free protein to the clay surfaces. Uncertainties in the calculation of the number of nucleation sites are estimated by propagating those stemming from the mass of mycelium in the initial suspensions, dilution errors, droplet volume errors and uncertainties which arise due to background freezing of the Milli- $Q^{\circledR}$ water. Background nucleation, stemming from impurities in the Milli- $\mathrm{Q}^{\circledR}$ water and the silanized-glass substrate, were subtracted out in the calculation of $K$ (further details of this procedure can be found elsewhere; O'Sullivan et al., 2015), although in practice these nucleation sites were many orders of magnitude less common than those of the PINP in suspension. 


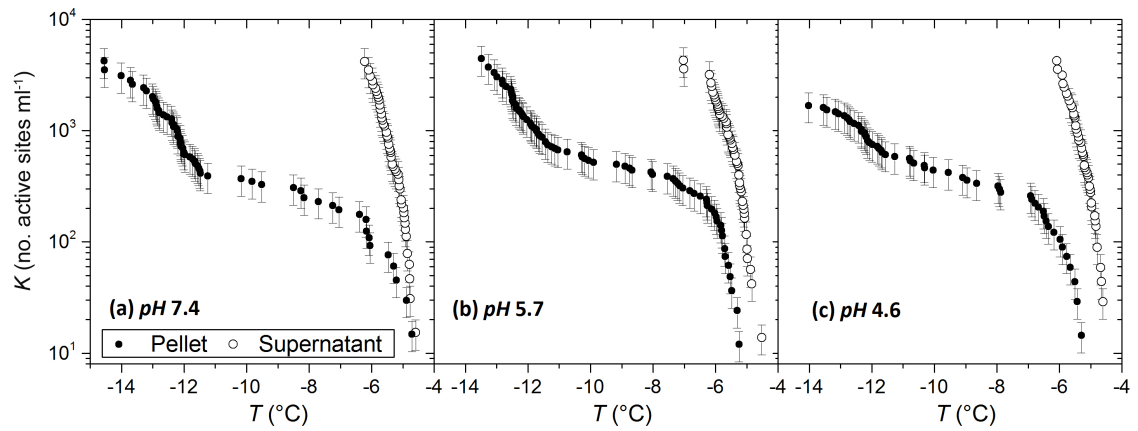

Figure 2. Effect of clay surfaces on fungal P-INPs in solution in the absence of added salts. The ice-nucleating activities of the supernatant and the resuspended clay removed by centrifugation of a suspension of fungal P-INPs and kaolinite are illustrated. The contact time was $2 \mathrm{~h}$. Regardless of the initial $\mathrm{pH}$ used, ice-nucleating activity is predominantly found in the supernatant, suggesting that adsorption only occurs to a minor extent, if at all.

\section{Results and discussion}

\subsection{Clay-protein interactions in the absence of electrolytes}

Initially, we investigated adsorption of P-INPs to the clay in the absence of added salts and the results are shown in Fig. 2. Values of $K$ (no. of ice-nucleating sites per $\mathrm{mL}$ of suspension, Eq. 1) are presented for suspensions where the initial $\mathrm{pH}$ was not adjusted (5.7) as well as where it was adjusted to 7.4 and 4.7 by addition of base or acid; this range of $\mathrm{pH}$ is relevant for typical topsoils. Measured $K$ values for kaolinite on its own (with no adjustment to $\mathrm{pH}$ ) are far below those of either the pellet or supernatant (Fig. S1). The open symbols in Fig. 2 are for the freezing of the supernatant after centrifuging the suspension, whereas the closed symbols are for the resuspended clay pellets. It is clear that the majority of the PINPs (around $90 \%$ of those active at $-7^{\circ} \mathrm{C}$ ) remained in the supernatant (Fig. 2) and did not strongly adsorb to the clay particles. This result was independent of $\mathrm{pH}$ within the range investigated. Hence, in the absence of added salts, adsorption to the clay was minimal. As adsorption is a time-dependent process, it is possible that extending the contact time could result in uptake of the protein to the clay. Nevertheless, the results here show that on timescales characteristic of protein adsorption to clays (Yu et al., 2013), uptake of the P-INP was minor in the absence of electrolytes.

Given the tendency of proteins to adsorb readily to clays (Zimmerman and Ahn, 2011; Yu et al., 2013), the absence of protein uptake to the clay observed here suggests that, in this $\mathrm{pH}$ range, repulsive interactions may inhibit adsorption. In kaolinite heterogeneous electrostatic charges exist at various points on the surface (Tombácz and Szekeres, 2006). Permanent negative charges develop in kaolinite due to isomorphic substitutions, along with $\mathrm{pH}$-dependent charges due to surface silanol and aluminol groups. In the range of $\mathrm{pH}$ studied, the silanol groups will likely be deprotonated, while aluminol groups become protonated below about pH 6.5 (Tombácz and
Szekeres, 2006). The presence of salt ions which are present in soils can significantly alter the nature of the electrostatic interactions, and promote cation exchange at the surface of the clays. Hence, the effects of adding salt ions such as $\mathrm{Na}^{+}$ and $\mathrm{Ca}^{2+}$ on the adsorption behaviour was further probed.

\subsection{Clay-protein interactions in the presence of electrolytes}

Solution ionic strength is known to be important in regulating the adsorption of proteins to solid surfaces (Yu et al., 2013; Rabe et al., 2011). To examine the impacts of ionic strength and the identity of salts on the uptake of the protein to the clay, salts were added to the suspension and the results are shown in Fig. 3. Ionic strengths of 1 and $10 \mathrm{mM}$ were chosen to approximate those found in soil solutions (Campbell et al., 1989; Griffin and Jurinak, 1973; Edmeades et al., 1985; Dolling and Ritchie, 1985). Control experiments in the absence of added kaolinite suggested no preferential settling of the protein in the electrolyte solution under centrifugation. After a contact time of $2 \mathrm{~h}$, only a minor enhancement in the extent of partitioning of P-INPs from the solution to the clay was observed when $1 \mathrm{mM} \mathrm{NaCl}$ was added (Fig. 3a, blue circles). However, for $1 \mathrm{mM} \mathrm{CaCl} 2$ a large increase in the uptake of the protein to the clay was found (Fig. 3a, red circles). When the contact time was increased to 2 days (Fig. 3b), a dramatic increase in the extent of adsorption to the clay was observed, with around $90 \%$ of INPs active at $-7^{\circ} \mathrm{C}$ now being associated with the kaolinite for both $1 \mathrm{mM}$ $\mathrm{CaCl}_{2}$ and $\mathrm{NaCl}$ solutions. These observations indicate that electrolytes can enhance the binding of ice-active fungal proteins to kaolinite and that the identity of the cations in solution influences the adsorption process.

On increasing the ionic strength of the solution to $10 \mathrm{mM}$ with $\mathrm{NaCl}$ (for a $2 \mathrm{~h}$ contact time), the amount of protein depleted from the supernatants was found to increase relative to when $1 \mathrm{mM}$ was used such that the activity of the clay matched that of the supernatant (Fig. 4a blue circles). 


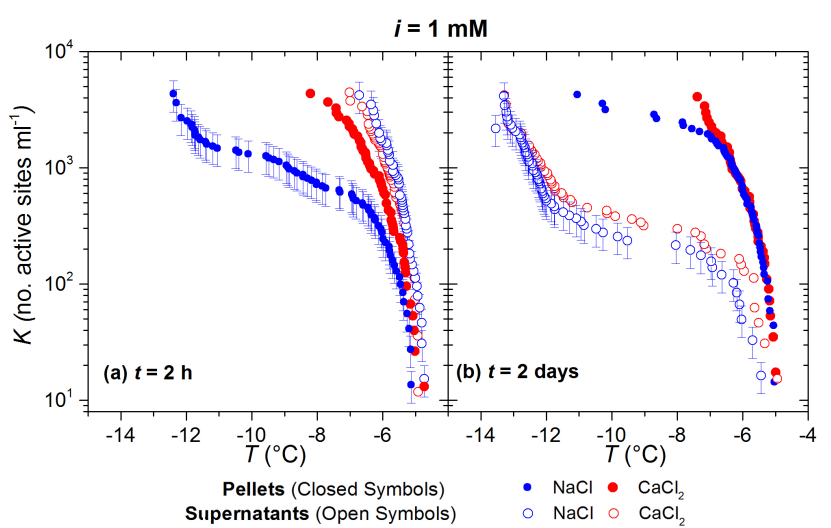

Figure 3. Effect of electrolytes at an ionic strength of $1 \mathrm{mM}$ on the uptake of P-INPs to the clay surface with a contact time of (a) $2 \mathrm{~h}$ and (b) 2 days. Initially, in (a) it can be seen that uptake to the clay is greater in the presence of $\mathrm{Ca}^{2+}$ (closed red circles) compared with $\mathrm{Na}^{+}$(closed blue circles), but after 2 days (b), the extent of adsorption is the similar regardless of the salt used. After 2 days, depletion of the free protein is extensive, with on the order of $90 \%$ of INPs active at $-7^{\circ} \mathrm{C}$ found to be associated with the clay.

Once again, in the presence of divalent ions, such as $\mathrm{Ca}^{2+}$ or $\mathrm{Mg}^{2+}$, an even larger depletion of the free protein in solution was found, with the amount of P-INP in the pellet now exceeding that in the supernatant (Fig. 4a). Similar to the case for an ionic strength of $1 \mathrm{mM}$, allowing an extended contact time of 2 days was found to lead to a further depletion of the free protein in the suspension. As can be seen in Fig. 4b, after 2 days the majority of the protein is found to be associated with the clay mineral, regardless of the salt used. The relatively rapid uptake of the ice-nucleating protein to the clay mineral kaolinite observed here is also consistent with previous studies of the adsorption of a variety of proteins, where adsorption has been found to reach equilibrium on timescales of minutes to hours (Ding and Henrichs, 2002; Lepoitevin et al., 2014; Ralla et al., 2010; Venkateswerlu and Stotzky, 1992). Such timescales are short on environmental timescales where cell-free proteins can have extended contact times with wet soil minerals.

The effect of adding salts to the suspensions here likely involves altering the extent of electrostatic interactions between proteins in the suspension and the kaolinite adsorbent, as electrolytes act to screen Coulombic interactions (Roth and Lenhoff, 1995; Rabe et al., 2011). Variations in ionic strength impact upon both the kinetics and equilibrium position of protein adsorption on solid surfaces (Rabe et al., 2011). With increasing ionic strength, adsorption of proteins (or protein domains) to oppositely charged substrates is diminished, while adsorption between proteins and substrates with the same charge is enhanced (Rabe et al., 2011). Furthermore, the presence of electrolytes can also enhance adsorption by reducing unfavourable lateral interactions between adsorbed proteins (Rabe et al., 2011). Together with

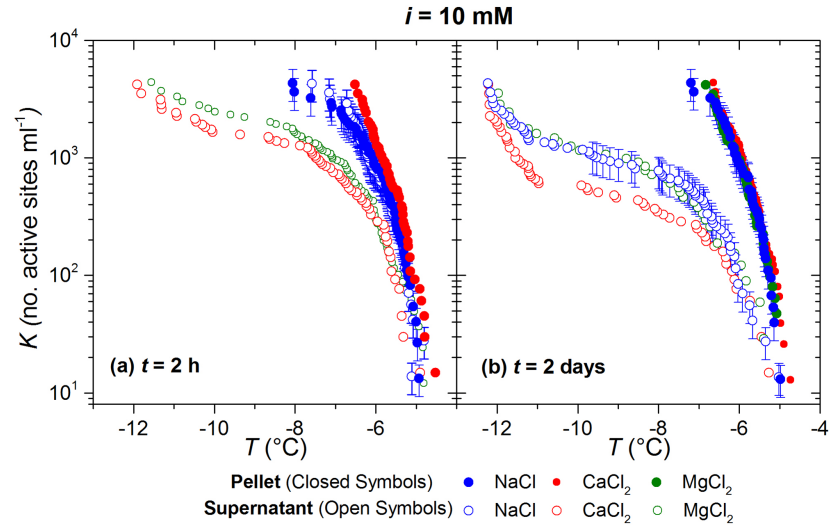

Figure 4. Effect of increasing ionic strength to $10 \mathrm{mM}$ on the uptake of P-INPs to the clay surface. The activities of the clay (closed symbols) and the supernatant (open symbols) after contact times of (a) $2 \mathrm{~h}$ and (b) 2 days are illustrated. After $2 \mathrm{~h}$, the extent of adsorption is observed to be greater than the case of when an ionic strength of $1 \mathrm{mM}$ is used (Fig. 3a). On increasing the contact time adsorption continues to proceed, where it can be seen that after 2 days, greater than $90 \%$ of the protein is adsorbed to the clay pellet (b).

the observed lack of adsorption across the $\mathrm{pH}$ range probed (Fig. 2), the impacts of ionic strength in the current work suggest that in the presence of added salts, repulsive electrostatic interactions are diminished, allowing shorter range attractive forces to dominate.

The increase in adsorption when a divalent cation is used rather than a monovalent one suggests that the character of the ion may also impact upon the adsorption process through mechanisms other than just the screening of negative charges. Similar results have previously been reported by Van Dulm et al. (1981) for the adsorption of proteins to negatively charged polystyrene surfaces. Effects such as relative abilities of different ions to act as bridges between proteins and surfaces of the same charge were suggested by the authors as possible reasons for preferential protein uptake in the presence of divalent salts.

In a wide variety of past studies of protein adsorption on clays, adsorption has been found to be accompanied by concurrent changes in activities of the proteins (Zimmerman and Ahn, 2011). While no effects, or even an enhancement in activity has been observed for certain enzymes, reduction in activity is a common feature of protein adsorption to mineral dusts (Zimmerman and Ahn, 2011; Calamai et al., 2000; Gianfreda et al., 1991; Hughes and Simpson, 1978). Such impairment of activities has been suggested to arise from conformational changes of the protein or the blocking of active sites upon adsorption (Rao et al., 2000; Leprince and Quiquampoix, 1996; Quiquampoix, 1987; Lozzi et al., 2001). In the current study, the continued activity of the adsorbed protein suggests that rapid inactivation in soils due to conformational changes upon adsorption does not take place and ac- 


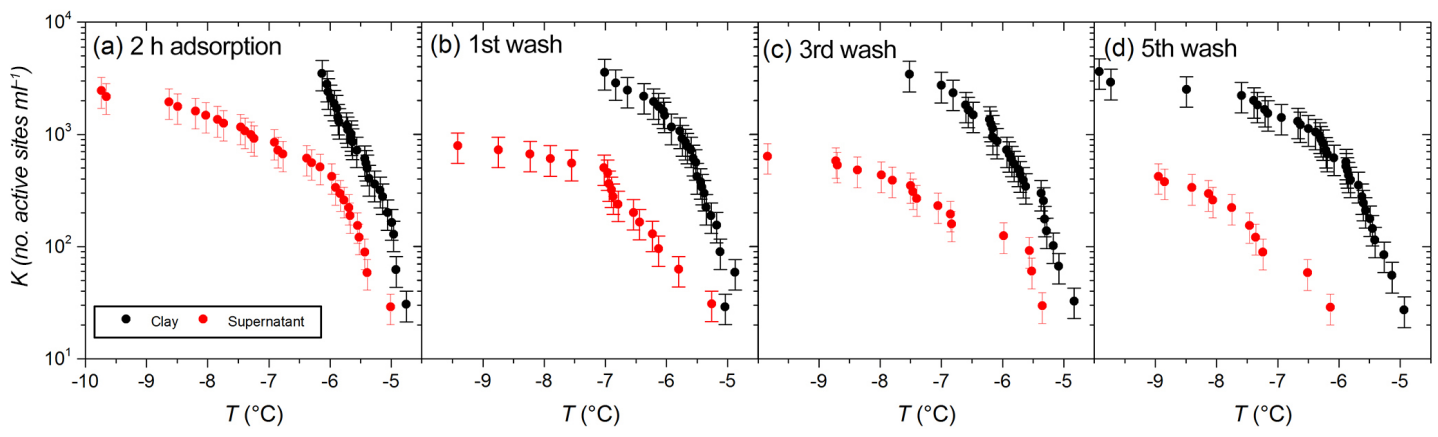

Figure 5. Effect of repeatedly washing the clay pellet by successive resuspension and centrifugation (see Fig. 1). Illustrated are (a) activities of the clay and supernatant after adsorption is allowed to proceed for $2 \mathrm{~h}$, and (b-d) the effects of successive washing of the clay pellet with pure water. After each washing cycle, on the order of $10 \%$ of the protein was observed to be lost to the supernatant, suggesting that the adsorption process is partially reversible. This is in addition to a maximum of $4 \%$ loss in each wash, due to the amount removed to conduct the droplet freezing experiments.

tivity is likely to be transferred to surrounding soil particles upon release of Fusarium P-INPs.

\subsection{Reversibility of Adsorption}

To examine the extent to which adsorption was reversible, the clay pellet was repeatedly washed, centrifuged and resuspended in Milli- $\mathrm{Q}^{\circledR}$ purified water, with the results indicated in Fig. 5. The first thing to note is that the clay pellet retains a substantial amount of fungal P-INPs even after five cycles of washing and centrifuging. However, with each wash the activity of the clay was observed to reduce, with around $10 \%$ of the protein lost to the supernatant on each cycle. The implication of this finding is that in soils the adsorption is at least partially reversible, which may have important consequences for the biodegradability of Fusarium P-INPs by soil microbes. The fact that a portion of the protein could be removed by washing further suggests that while the majority of the fungal P-INPs are likely to be bound to clay minerals in soils, they are not so tightly bound so as to prevent diffusion of the protein in soils over time. Accordingly, fungal P-INPs may leach into surface and ground waters, leading to the migration of fungal P-INPs to other soil surfaces spatially removed from the original source of the ice-nucleating fungus (Helassa et al., 2009).

\section{Conclusions}

Although certain biological particles harbour the most efficient naturally occurring ice nucleation sites known, the roles biological particles play in cloud ice formation remain poorly constrained. Currently, there is a growing awareness that subcellular biological fragments from organisms, such as bacteria, pollen and fungi may be important atmospheric INPs (O'Sullivan et al., 2015; Pummer et al., 2012, 2015; Augustin et al., 2013; Fröhlich-Nowoisky et al., 2015; Šantl-Temkiv et al., 2015; Rangel Alvarado et al., 2015).
However, our knowledge of the environmental processing of these biomolecular INPs, such as that which occurs in soils, currently limits our abilities to assess their contributions to airborne particles possessing efficient ice-nucleating sites. Whether these nanoscale fragments may add to the reservoir of INPs found in topsoils depends critically on whether activity is preserved upon adsorption to soil minerals.

In this study we have demonstrated that proteinaceous INPs from a common soil-borne fungus are preferentially partitioned to clay surfaces in the presence of watercontaining electrolytes commonly found in soil solutions. Upon adsorption, the exceptional ice-nucleating activity of the fungal P-INPs was maintained, suggesting that the adsorption process does not inactivate the efficient nucleating abilities of the protein. Accordingly, fungal P-INPs are likely to confer activity to soil particles once removed from mycelia by wetting, although further environmental processing, such as repeated wetting and drying of soils, could potentially perturb protein activity. The fact that a minor amount of the protein could be removed from the clay suggests that adsorption to the clay was reversible, which is an important observation for the environmental fates of fungal P-INPs. With adsorption being reversible, the protein may be leachable by surface waters and can potentially migrate to other soil surfaces distant from the original source fungi (Helassa et al., 2009). Furthermore, the fact that a minor portion of the protein could be desorbed upon washing suggests that the protein may be accessible as a nutrient source for soil microbes, making it more susceptible to biodegradation (Fiorito et al., 2008; Gianfreda et al., 1991; Dashman and Stotzky, 1986). Consequently, future work should be aimed at addressing the issue of ice-active protein lifetime with respect to biodegradation in soils.

The persistence of P-INP activity following adsorption to soil minerals has important implications for our understandings of the roles which biological entities may play as sources of atmospheric INPs. As recently suggested, biogenic mat- 
ter residues within soil dusts are potentially the largest contributor to the burden of atmospheric INPs at temperatures above $-15^{\circ} \mathrm{C}$ on a global basis (O'Sullivan et al., 2014; Conen et al., 2011). Indeed, the characteristics of the organoclay INPs examined in this study are similar to the efficient INPs which have been identified in topsoils (O'Sullivan et al., 2015; Conen et al., 2011), a substantial proportion of which were shown to be thermally labile and exhibit exceptional ice-nucleating abilities. In addition to Fusaria, other organisms can also contribute to the reservoir of cell-free P-INPs in soils, such as the fungus $M$. alpina (Fröhlich-Nowoisky et al., 2015), certain lichens (Kieft and Ruscetti, 1990) and even ice-nucleating bacteria (Phelps et al., 1986). For Fusaria, icenucleating activity has been observed in a number of species, and species such as Fusaria are widespread in soils, occurring across the globe wherever crops are grown (Pitt et al., 2009). This, together with the fact that the contribution of dusts from agricultural regions to the total dust emissions is estimated to be in the region of $25 \%$ (Ginoux et al., 2012), means mineral-bound proteins from Fusaria and other fungi may be a major source of the rare particles capable of nucleating cloud ice at temperatures above $-15^{\circ} \mathrm{C}$. However, not every strain of the five known ice nucleation active Fusarium species produce efficient INPs (Pouleur et al., 1992; Richard et al., 1996). While Fusaria such as F. avenaceum are globally distributed, the relative abundances of each species is governed by factors such as climate and land use (West et al., 2012). The impact of these factors on the distributions of P-INP producing Fusaria has yet to be fully discerned. This, together with studies of the biodegradability of fungal P-INPs, will be required to further constrain the net contributions these particles make to the source strength of biological INPs lofted to the atmosphere.

\section{Data availability}

The datasets for this paper will be made publicly available using the University of Leeds Data Repository (doi:10.5518/78; O’Sullivan et al., 2016).

\section{The Supplement related to this article is available online at doi:10.5194/acp-16-7879-2016-supplement.}

Author contributions. Daniel O'Sullivan designed and conducted the ice nucleation experiments, analysed the data and authored the manuscript. Benjamin J. Murray and Michael E. Webb oversaw the project and helped to write the manuscript. James F. Ross assisted with the culturing of the fungi and with the data analysis. The authors declare no competing financial interests.
Acknowledgements. The authors would like to acknowledge the National Environmental Research Council, (NERC, NE/I013466/1; NE/K004417/1), the European Research Council, (ERC, 240449 ICE; 648661 MarineIce) and the Engineering and Physical Science Research Council (EPSRC; EP/M003027/1) for funding this research.

Edited by: A. E. Perring

\section{References}

Augustin, S., Wex, H., Niedermeier, D., Pummer, B., Grothe, H., Hartmann, S., Tomsche, L., Clauss, T., Voigtländer, J., Ignatius, K., and Stratmann, F.: Immersion freezing of birch pollen washing water, Atmos. Chem. Phys., 13, 10989-11003, doi:10.5194/acp-13-10989-2013, 2013.

Augustin-Bauditz, S., Wex, H., Denjean, C., Hartmann, S., Schneider, J., Schmidt, S., Ebert, M., and Stratmann, F.: Laboratorygenerated mixtures of mineral dust particles with biological substances: characterization of the particle mixing state and immersion freezing behavior, Atmos. Chem. Phys., 16, 5531-5543, doi:10.5194/acp-16-5531-2016, 2016.

Boucher, O., Randall, D., Artaxo, P., Bretherton, C., Feingold, G., Forster, P., Kerminen, V.-M., Kondo, Y., Liao, H., Lohmann, U., Rasch, P., Satheesh, S. K., Sherwood, S., Stevens, B., and Zhang, X. Y.: Climate Change 2013: The Physical Science Basis. Contribution of Working Group I to the Fifth Assessment Report of the Intergovernmental Panel on Climate Change, edited by: Stocker, T. F., Qin, D., Plattner, G.-K., Tignor, M., Allen, S. K., Boschung, J., Nauels, A., Xia, Y., Bex, V., and Midgley, P. M., Cambridge University Press, Cambridge, UK, 2013.

Calamai, L., Lozzi, I., Stotzky, G., Fusi, P., and Ristori, G.: Interaction of catalase with montmorillonite homoionic to cations with different hydrophobicity: effect on enzymatic activity and microbial utilization, Soil Biol. Biochem., 32, 815-823, doi:10.1016/S0038-0717(99)00211-4, 2000.

Campbell, D., Kinniburgh, D., and Beckett, P.: The soil solution chemistry of some Oxfordshire soils: temporal and spatial variability, J. Soil Sci., 40, 321-339, doi:10.1111/j.13652389.1989.tb01277.x, 1989.

Conen, F., Morris, C. E., Leifeld, J., Yakutin, M. V., and Alewell, C.: Biological residues define the ice nucleation properties of soil dust, Atmos. Chem. Phys., 11, 9643-9648, doi:10.5194/acp-119643-2011, 2011.

Creamean, J. M., Suski, K. J., Rosenfeld, D., Cazorla, A., DeMott, P. J., Sullivan, R. C., White, A. B., Ralph, F. M., Minnis, P., Comstock, J. M., Tomlinson, J. M., and Prather, K. A.: Dust and Biological Aerosols from the Sahara and Asia Influence Precipitation in the Western U.S, Science, 339, 1572-1578, doi:10.1126/science.1227279, 2013.

Dashman, T. and Stotzky, G.: Microbial utilization of amino acids and a peptide bound on homoionic montmorillonite and kaolinite, Soil Biol. Biochem., 18, 5-14, doi:10.1016/00380717(86)90096-9, 1986.

DeMott, P. J., Prenni, A. J., Liu, X., Kreidenweis, S. M., Petters, M. D., Twohy, C. H., Richardson, M. S., Eidhammer, T., and Rogers, D. C.: Predicting global atmospheric ice nuclei distributions and 
their impacts on climate, P. Natl. Acad Sci. USA, 107, 1121711222, doi:10.1073/pnas.0910818107, 2010.

Ding, X. and Henrichs, S. M.: Adsorption and desorption of proteins and polyamino acids by clay minerals and marine sediments, Mar. Chem., 77, 225-237, doi:10.1016/S0304-4203(01)00085$8,2002$.

Dolling, P. and Ritchie, G.: Estimates of soil solution ionic strength and the determination of $\mathrm{pH}$ in West Australian soils, Soil Res., 23, 309-314, doi:10.1071/Sr9850309, 1985.

Edmeades, D., Wheeler, D., and Clinton, O.: The chemical composition and ionic strength of soil solutions from New Zealand topsoils, Soil Res., 23, 151-165, doi:10.1071/SR9850151, 1985.

Fiorito, T. M., Icoz, I., and Stotzky, G.: Adsorption and binding of the transgenic plant proteins, human serum albumin, $\beta$-glucuronidase, and $\mathrm{Cry} 3 \mathrm{Bb} 1$, on montmorillonite and kaolinite: Microbial utilization and enzymatic activity of free and clay-bound proteins, Appl. Clay Sci., 39, 142-150, doi:10.1016/j.clay.2007.07.006, 2008.

Fröhlich-Nowoisky, J., Hill, T. C. J., Pummer, B. G., Yordanova, P., Franc, G. D., and Pöschl, U.: Ice nucleation activity in the widespread soil fungus Mortierella alpina, Biogeosciences, 12, 1057-1071, doi:10.5194/bg-12-1057-2015, 2015.

Gianfreda, L., Rao, M., and Violante, A.: Invertase $\beta$-fructosidase): Effects of montmorillonite, AL-hydroxide and AL (OH) $x$ montmorillonite complex on activity and kinetic properties, Soil Biol. Biochem., 23, 581-587, doi:10.1016/0038-0717(91)901162, 1991.

Ginoux, P., Prospero, J. M., Gill, T. E., Hsu, N. C., and Zhao, M.: Global-scale attribution of anthropogenic and natural dust sources and their emission rates based on MODIS Deep Blue aerosol products, Rev. Geophys., 50, RG3005, doi:10.1029/2012rg000388, 2012.

Griffin, B. and Jurinak, J.: Estimation of activity coefficients from the electrical conductivity of natural aquatic systems and soil extracts, Soil Sci., 116, 26-30, 1973.

Hasegawa, Y., Ishihara, Y., and Tokuyama, T.: Characteristics of ice-nucleation activity in Fusarium avenaceum IFO 7158, Biosci. Biotech. Biochem., 58, 2273-2274, doi:10.1271/bbb.58.2273, 1994.

Helassa, N., Quiquampoix, H., Noinville, S., Szponarski, W., and Staunton, S.: Adsorption and desorption of monomeric $\mathrm{Bt}$ (Bacillus thuringiensis) Cry1Aa toxin on montmorillonite and kaolinite, Soil Biol. Biochem., 41, 498-504, doi:10.1016/j.soilbio.2008.12.008, 2009.

Hill, T. C. J., DeMott, P. J., Tobo, Y., Fröhlich-Nowoisky, J., Moffett, B. F., Franc, G. D., and Kreidenweis, S. M.: Sources of organic ice nucleating particles in soils, Atmos. Chem. Phys., 16, 7195-7211, doi:10.5194/acp-16-7195-2016, 2016.

Hoose, C. and Möhler, O.: Heterogeneous ice nucleation on atmospheric aerosols: a review of results from laboratory experiments, Atmos. Chem. Phys., 12, 9817-9854, doi:10.5194/acp-12-98172012, 2012.

Hoose, C., Kristjánsson, J. E., Chen, J. P., and Hazra, A.: A Classical-Theory-Based Parameterization of Heterogeneous Ice Nucleation by Mineral Dust, Soot, and Biological Particles in a Global Climate Model, J. Atmos. Sci., 67, 2483-2503, doi:10.1175/2010JAS3425.1, 2010.
Hughes, J. and Simpson, G.: Arylsulphatase clay interactions. II. The effect of kaolinite and montmorillonite on arylsulphatase activity, Soil Res., 16, 35-40, doi:10.1071/SR9780035, 1978.

Kieft, T. L. and Ruscetti, T.: Characterization of biological ice nuclei from a lichen, J. Bacteriol., 172, 3519-3523, 1990.

Koskella, J. and Stotzky, G.: Microbial utilization of free and claybound insecticidal toxins from Bacillus thuringiensis and their retention of insecticidal activity after incubation with microbes, Appl. Environ. Microbiol., 63, 3561-3568, 1997.

Lepoitevin, M., Jaber, M., Guegan, R., Janot, J. M., Dejardin, P., Henn, F., and Balme, S.: BSA and lysozyme adsorption on homoionic montmorillonite: Influence of the interlayer cation, Appl. Clay Sci., 95, 396-402, doi:10.1016/j.clay.2014.05.003, 2014.

Leprince, F. and Quiquampoix, H.: Extracellular enzyme activity in soil: effect of $\mathrm{pH}$ and ionic strength on the interaction with montmorillonite of two acid phosphatases secreted by the ectomycorrhizal fungus Hebeloma cylindrosporum, Eur. J. Soil Sci., 47, 511-522, doi:10.1111/j.1365-2389.1996.tb01851.x, 1996.

Lozzi, I., Calamai, L., Fusi, P., Bosetto, M., and Stotzky, G.: Interaction of horseradish peroxidase with montmorillonite homoionic to $\mathrm{Na}^{+}$and $\mathrm{Ca}^{2+}$ : effects on enzymatic activity and microbial degradation, Soil Biol. Biochem., 33, 1021-1028, doi:10.1016/S0038-0717(01)00005-0, 2001.

Murray, B. J., O'Sullivan, D., Atkinson, J. D., and Webb, M. E.: Ice nucleation by particles immersed in supercooled cloud droplets, Chem. Soc. Rev., 41, 6519-6554, doi:10.1039/c2cs35200a, 2012.

O’Sullivan, D., Murray, B. J., Malkin, T. L., Whale, T. F., Umo, N. S., Atkinson, J. D., Price, H. C., Baustian, K. J., Browse, J., and Webb, M. E.: Ice nucleation by fertile soil dusts: relative importance of mineral and biogenic components, Atmos. Chem. Phys., 14, 1853-1867, doi:10.5194/acp-14-1853-2014, 2014.

O’Sullivan, D., Murray, B. J., Ross, J. F., Whale, T. F., Price, H. C., Atkinson, J. D., Umo, N. S., and Webb, M. E.: The relevance of nanoscale biological fragments for ice nucleation in clouds, Scientific reports, 5, 8082, doi:10.1038/srep08082, 2015.

O'Sullivan, D., Murray, B. J., Ross, J. F., and Webb, M. E.: Cumulative ice nucleation spectra for "The adsorption of fungal ice-nucleating proteins on mineral dusts: a terrestrial reservoir of atmospheric ice-nucleating particles", University of Leeds Data Repository, doi:10.5518/78, 2016.

Phelps, P., Giddings, T. H., Prochoda, M., and Fall, R.: Release of cell-free ice nuclei by Erwinia herbicola, J. Bacteriol., 167, 496502, 1986.

Pitt, J. I., Hocking, A. D., and Diane, A.: Fungi and food spoilage, 3rd Edn., Springer, Sydney, 2009.

Pouleur, S., Richard, C., Martin, J. G., and Antoun, H.: Ice nucleation activity in Fusarium acuminatum and Fusarium avenaceum, Appl. Environ. Microbiol., 58, 2960-2964, 1992.

Pratt, K. A., DeMott, P. J., French, J. R., Wang, Z., Westphal, D. L., Heymsfield, A. J., Twohy, C. H., Prenni, A. J., and Prather, K. A.: In situ detection of biological particles in cloud ice-crystals, Nat. Geosci., 2, 398-401, doi:10.1038/NGEO521, 2009.

Pruppacher, H. R., and Klett, J. D.: Microphysics of Clouds and Precipitation, Kluwer Academic Publishers, New York, 1997.

Pummer, B. G., Bauer, H., Bernardi, J., Bleicher, S., and Grothe, H.: Suspendable macromolecules are responsible for ice nucle- 
ation activity of birch and conifer pollen, Atmos. Chem. Phys., 12, 2541-2550, doi:10.5194/acp-12-2541-2012, 2012.

Pummer, B. G., Budke, C., Augustin-Bauditz, S., Niedermeier, D., Felgitsch, L., Kampf, C. J., Huber, R. G., Liedl, K. R., Loerting, T., Moschen, T., Schauperl, M., Tollinger, M., Morris, C. E., Wex, H., Grothe, H., Pöschl, U., Koop, T., and FröhlichNowoisky, J.: Ice nucleation by water-soluble macromolecules, Atmos. Chem. Phys., 15, 4077-4091, doi:10.5194/acp-15-40772015, 2015.

Quiquampoix, H.: A stepwise approach to the understanding of extracellular enzyme activity in soil I. Effect of electrostatic interactions on the conformation of a $\beta$-D-glucosidase adsorbed on different mineral surfaces, Biochimie, 69, 753-763, doi:10.1016/0300-9084(87)90196-9, 1987.

Rabe, M., Verdes, D., and Seeger, S.: Understanding protein adsorption phenomena at solid surfaces, Adv. Colloid Interfac., 162, 87-106, doi:10.1016/j.cis.2010.12.007, 2011.

Ralla, K., Sohling, U., Riechers, D., Kasper, C., Ruf, F., and Scheper, T.: Adsorption and separation of proteins by a smectitic clay mineral, Bioprocess Biosystems Eng., 33, 847-861, doi:10.1007/s00449-010-0408-8, 2010.

Rangel Alvarado, R. B., Nazarenko, Y., and Ariya, P. A.: Snow borne nanosized particles: Abundance, distribution, composition, and significance in ice nucleation processes, J. Geophys. Res.Atmos., 120, 11760-11774, doi:10.1002/2015JD023773, 2015.

Rao, M. A., Violante, A., and Gianfreda, L.: Interaction of acid phosphatase with clays, organic molecules and organo-mineral complexes: kinetics and stability, Soil Biol. Biochem., 32, 10071014, doi:10.1016/S0038-0717(00)00010-9, 2000.

Richard, C., Martin, J. G., and Pouleur, S.: Ice nucleation activity identified in some phytopathogenic Fusarium species, Phytoprotection, 77, 83-92, 1996.

Rosenfeld, D., Yu, X., Liu, G. H., Xu, X. H., Zhu, Y. N., Yue, Z. G., Dai, J., Dong, Z. P., Dong, Y., and Peng, Y.: Glaciation temperatures of convective clouds ingesting desert dust, air pollution and smoke from forest fires, Geophys. Res. Lett., 38, L21804, doi:10.1029/2011g1049423, 2011.

Roth, C. M. and Lenhoff, A. M.: Electrostatic and van der Waals Contributions to Protein Adsorption: Comparison of Theory and Experiment, Langmuir, 11, 3500-3509, doi:10.1021/la00009a036, 1995.

Šantl-Temkiv, T., Sahyoun, M., Finster, K., Hartmann, S., AugustinBauditz, S., Stratmann, F., Wex, H., Clauss, T., Nielsen, N. W., and Sørensen, J. H.: Characterization of airborne ice-nucleationactive bacteria and bacterial fragments, Atmos. Environ., 109, 105-117, doi:10.1016/j.atmosenv.2015.02.060, 2015.

Schmidt, M. W. I., Torn, M. S., Abiven, S., Dittmar, T., Guggenberger, G., Janssens, I. A., Kleber, M., Kogel-Knabner, I., Lehmann, J., Manning, D. A. C., Nannipieri, P., Rasse, D. P., Weiner, S., and Trumbore, S. E.: Persistence of soil organic matter as an ecosystem property, Nature, 478, 49-56, doi:10.1038/nature10386, 2011.

Schnell, R. and Vali, G.: Freezing nuclei in marine waters, Tellus, 27, 321-323, doi:10.1111/j.2153-3490.1975.tb01682.x, 1975.

Schnell, R. C.: Kaolin and a Biogenic Ice Nucleant: Some Nucleation and Identification Studies, IX Nucleation Conference, Galway, Ireland, 353-356, 1977.
Storelvmo, T., Hoose, C., and Eriksson, P.: Global modeling of mixed-phase clouds: The albedo and lifetime effects of aerosols, J. Geophys. Res.-Atmos., 116, D05207, doi:10.1029/2010jd014724, 2011.

Tobo, Y., DeMott, P. J., Hill, T. C. J., Prenni, A. J., SwobodaColberg, N. G., Franc, G. D., and Kreidenweis, S. M.: Organic matter matters for ice nuclei of agricultural soil origin, Atmos. Chem. Phys., 14, 8521-8531, doi:10.5194/acp-14-8521-2014, 2014.

Tombácz, E. and Szekeres, M.: Surface charge heterogeneity of kaolinite in aqueous suspension in comparison with montmorillonite, Appl. Clay Sci., 34, 105-124, doi:10.1016/j.clay.2006.05.009, 2006.

Vali, G.: Quantitative Evaluation of Experimental Results an the Heterogeneous Freezing Nucleation of Supercooled Liquids, J. Atmos. Sci., 28, 402-409, 1971.

Van Dulm, P., Norde, W., and Lyklema, J.: Ion participation in protein adsorption at solid surfaces, J. Colloid Interf. Sci., 82, 77-82, doi:10.1016/0021-9797(81)90125-9, 1981.

Venkateswerlu, G. and Stotzky, G.: Binding of the Protoxin and Toxin Proteins of Bacillus-Thuringiensis Subsp Kurstaki on Clay-Minerals, Curr. Microbiol., 25, 225-233, doi:10.1007/Bf01570723, 1992.

West, J. S., Holdgate, S., Townsend, J. A., Edwards, S. G., Jennings, P., and Fitt, B. D. L.: Impacts of changing climate and agronomic factors on fusarium ear blight of wheat in the UK, Fungal Ecol., 5, 53-61, doi:10.1016/j.funeco.2011.03.003, 2012.

Whale, T. F., Murray, B. J., O’Sullivan, D., Wilson, T. W., Umo, N. S., Baustian, K. J., Atkinson, J. D., Workneh, D. A., and Morris, G. J.: A technique for quantifying heterogeneous ice nucleation in microlitre supercooled water droplets, Atmos. Meas. Tech., 8, 2437-2447, doi:10.5194/amt-8-2437-2015, 2015.

Wilson, T. W., Ladino, L. A., Alpert, P. A., Breckels, M. N., Brooks, I. M., Browse, J., Burrows, S. M., Carslaw, K. S., Huffman, J. A., Judd, C., Kilthau, W. P., Mason, R. H., McFiggans, G., Miller, L. A., Najera, J. J., Polishchuk, E., Rae, S., Schiller, C. L., Si, M., Temprado, J. V., Whale, T. F., Wong, J. P., Wurl, O., Yakobi-Hancock, J. D., Abbatt, J. P., Aller, J. Y., Bertram, A. K., Knopf, D. A., and Murray, B. J.: A marine biogenic source of atmospheric ice-nucleating particles, Nature, 525, 234-238, doi:10.1038/nature14986, 2015.

Yu, W. H., Li, N., Tong, D. S., Zhou, C. H., Lin, C. X., and Xu, C. Y.: Adsorption of proteins and nucleic acids on clay minerals and their interactions: A review, Appl. Clay Sci., 80-81, 443452, doi:10.1016/j.clay.2013.06.003, 2013.

Zimmerman, A. R. and Ahn, M.: Soil Enzymology, in: Soil Biology, Vol. 22, edited by: Shukla, G. and Varma, A., 271292, Springer-Verlag, Heidelberg Berlin, doi:10.1007/978-3642-14225-3, 2011. 